\title{
Investigation of the Bruce effect in the Mongolian gerbil (Meriones unguiculatus)
}

\author{
Carmen Rohrbach \\ Max-Planck-Institut für Verhaltensphysiologie, Abteilung Wickler, D 8031 Seewiesen, \\ West Germany
}

\begin{abstract}
Summary. Strange males and females blocked implantation in recently mated female Mongolian gerbils. Even the presence of the partner male failed to annul the influence. The females were, however, affected only when not lactating (e.g. in first pregnancies or when a litter had died). Pregnancies could also be ended by alterations of the caging conditions, but there were quantitative differences between social and non-social influences, both in numbers of females reacting and in their subsequent fertility. These results with gerbils do not support the suggestion that the biological advantage of pregnancy blocking lies in enhanced male reproductive success.
\end{abstract}

\section{Introduction}

As Bruce discovered in 1959, the presence of a strange male mouse blocks pregnancy in a newly mated female (Bruce effect). This has been examined chiefly in stocks of inbred laboratory mice, Mus musculus (Bruce, 1960a, 1962; Bruce \& Parrott, 1960), but has also been detected in wild house mice, $M$. musculus; deer mice, Peromyscus maniculatus; Pennsylvanian vole, Microtus pennsylvanicus, and the field vole, Microtus agrestis (Bronson \& Eleftheriou, 1963; Chipman \& Fox, 1966; Clulow \& Clarke, 1968; Mallory \& Clulow, 1977). This paper investigates whether the effect is also present in the Mongolian gerbil, Meriones unguiculatus. The aggressive nature of Mongolian gerbils normally precludes contact with strange males unless the very strong family or pair bonds are changed or destroyed, as for example when strange conspecifics encroach on the territory, or environmental factors necessitate emigration. This study has tested females with strange males, and also female reaction to possible natural social and non-social changes.

\section{Materials and General Methods}

Test animals were Mongolian gerbils which have been bred at our Institute since 1974. The Makrolon housing, breeding and test boxes measured $50 \times 35 \times 20 \mathrm{~cm}$ (Type A) or $30 \times 15 \times$ $13 \mathrm{~cm}$ (Type B). Before the introduction of each pair, cages were washed with a $10 \%$ Sagrotan solution and strewn with a $3 \mathrm{~cm}$ layer of fresh sawdust, removed after completion of every test and controls. Half a flowerpot served as shelter. Room temperature was kept at $20-22^{\circ} \mathrm{C}$, with a $12 \mathrm{~h}$ light: $12 \mathrm{~h}$ dark cycle. The animals were fed daily ad libitum with a dry food mixture of 
flaked dog food, sunflower seeds, Vitakraft rabbit fodder, and apples, carrots and fresh lettuce were given once weekly. Water was available in standard trade receptacles.

Pairs of young animals 20-30 days old were placed in one half of Type A cages divided by aluminium sheets with $\sim 3 \mathrm{~mm}$ air holes, or in undivided Type B cages. At the onset of sexual maturity (about 90-120 days) the vaginal membrane became perforate and the first oestrus occurred. Copulation followed, and its efficacy was shown when the female gave birth.

Each test began about $12 \mathrm{~h}$ after a copulation at the post-partum oestrus. Before the test the young and the partner male (except in Exp. I, Group 2) were removed from the cage. The test male or test female was then placed in the cage as indicated in Text-fig. 1. In Exp. I, Group 4 the female was separated from the partner male at the beginning of oestrus and a strange male was placed with her as mating male. After copulation the strange male was removed, and the partner male was placed in the formerly empty cage half. In Exp. II, Groups 1-7 Type B cages were used. In control tests the female stayed alone. A second control, in which the mating male was placed in the formerly empty cage half, was carried out in Exp. I, Groups 1 and 4 only. Controls and tests alternated for each female (each animal was used for tests for 1 year). Controls and tests each lasted 10 days. Vaginal smears were taken daily between 08:00 and 09:00 h. Implantation was presumed to have failed if the female came into oestrus again after 4-5 days, as shown by typical cells (Schollen) in the vaginal smears.

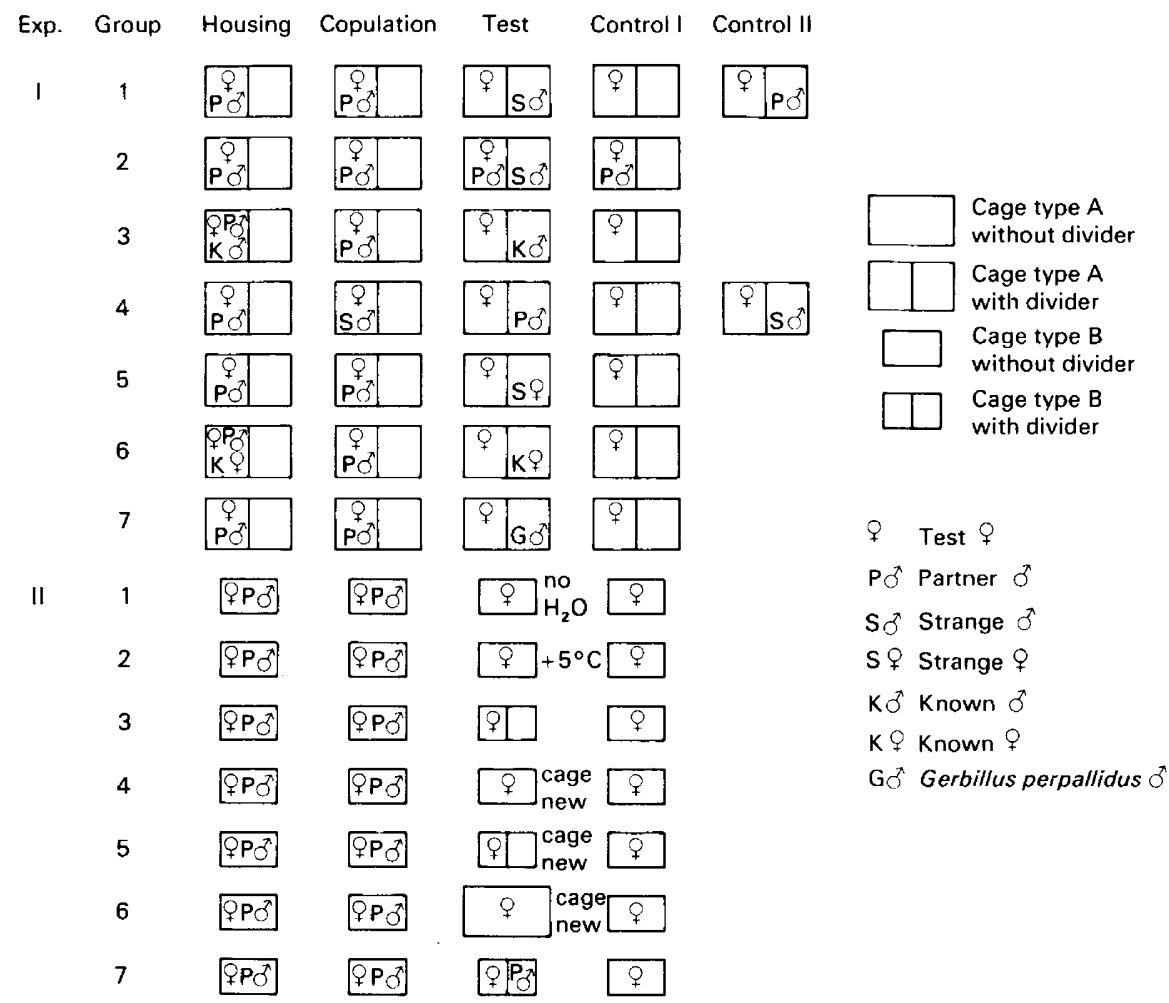

Text-fig. 1. Diagram to show the 14 experimental groups in Exps I and II.

\section{Terms used}

Partner male: one housed in same cage as the female since weaning; can also be the female's mate;

Strange male: one without contact with female before the experiment, but caged in same room. In Exp. I, Group 4 the strange male was also the mating male; 
Known male: one housed in same cage as the female and her partner male, but never having mated with the female;

Strange female: one without previous contact with the test female, but caged in the same room;

Known female: one housed in the same cage as the test female and partner male.

\section{Detailed Methods and Results}

\section{Effects of social and non-social factors}

The results for all tests and controls are given in Table 1. Strange females as well as strange males were able to block implantation (Exp. I, Groups 1 and 5). The presence of the partner male did not shield the female from this influence (Exp. I, Group 2). The partner male himself could prevent an implantation stemming from a strange male (Exp. I, Group 4). A known male or female, or a male of another species, had no influence on the pregnancy (Exp. I, Groups 3, 6 and 7).

Table 1. The results of Experiments I and II on implantation blockage in Mongolian gerbils

\begin{tabular}{|c|c|c|c|c|c|c|c|c|}
\hline \multirow{3}{*}{$\frac{\text { Exp. }}{\text { I }}$} & \multirow{3}{*}{$\frac{\text { Group }}{1}$} & \multirow[b]{2}{*}{ Treatment* } & \multicolumn{3}{|c|}{ Experiments } & \multicolumn{3}{|c|}{ Controls I, II $\dagger$} \\
\hline & & & \multirow{2}{*}{$\begin{array}{c}\begin{array}{c}\text { No. of } \\
\text { कq } \\
\text { tested }\end{array} \\
31\end{array}$} & \multicolumn{2}{|c|}{$\begin{array}{c}\text { No. of } \$ \uparrow \\
\text { not implanting } \\
(\%)\end{array}$} & \multirow{2}{*}{$\begin{array}{c}\text { No. of } \\
\begin{array}{c}\text { } \% \\
\text { tested }\end{array} \\
20,20\end{array}$} & \multicolumn{2}{|c|}{$\begin{array}{c}\text { No. of } \$ \uparrow \\
\text { not implanting } \\
(\%)\end{array}$} \\
\hline & & Strange $\delta$ & & 26 & $(83 \cdot 8)$ & & 0,0 & $(0,0)$ \\
\hline & 2 & Strange $\delta+$ Partner $\partial$ & 20 & 13 & $(65)$ & 20 & 0 & (0) \\
\hline & 3 & Known $\sigma^{\pi}$ & 10 & 0 & $(0)$ & & 0 & (0) \\
\hline & 4 & Partner $\delta$ & 20 & 15 & (75) & 20,20 & 1,2 & $(5,0)$ \\
\hline & 5 & Strange $\subsetneq$ & 21 & 20 & $(95 \cdot 2)$ & 20 & 0 & (0) \\
\hline & 6 & Known $q$ & 10 & 0 & $(0)$ & 10 & 0 & (0) \\
\hline & 7 & Gerbillus o & 10 & 0 & (0) & 10 & 0 & $(0)$ \\
\hline \multirow[t]{7}{*}{ II } & 1 & No water & 10 & 0 & $(0)$ & 10 & 0 & $(0)$ \\
\hline & 2 & Cold & 20 & 6 & (30) & 20 & 0 & $(0)$ \\
\hline & 3 & Smaller cage & 20 & 4 & (20) & 20 & 0 & (0) \\
\hline & 4 & New cage & 20 & 4 & (20) & 20 & 0 & (0) \\
\hline & 5 & New, smaller cage & 20 & 10 & (50) & 20 & 0 & (0) \\
\hline & 6 & New, larger cage & 20 & 4 & (20) & 20 & 0 & (0) \\
\hline & 7 & Smaller cage + Partner $\delta$ & 20 & 3 & (15) & 20 & 0 & $(0)$ \\
\hline
\end{tabular}

* See Text-fig. 1 .

$\dagger$ See text.

When all results were compared and tested against controls for significance (Fisher exact probability test; Siegel, 1956), it was shown that social and non-social factors could prevent implantation in a gerbil female (Text-fig. 2), but non-social changes showed a significantly lower blocking rate (Table 1).

After the 10 days of tests and controls, all females were again housed with their partner males and the interval between reunion and the new litter was recorded. This was found to depend (Text-fig. 3) on the female's previous test experience. If implantation had been blocked by the presence of conspecifics she next littered after 24-34 days, indicating immediate receptivity after blocking. But if environmental change was responsible her next litter followed after 26-110 days. 


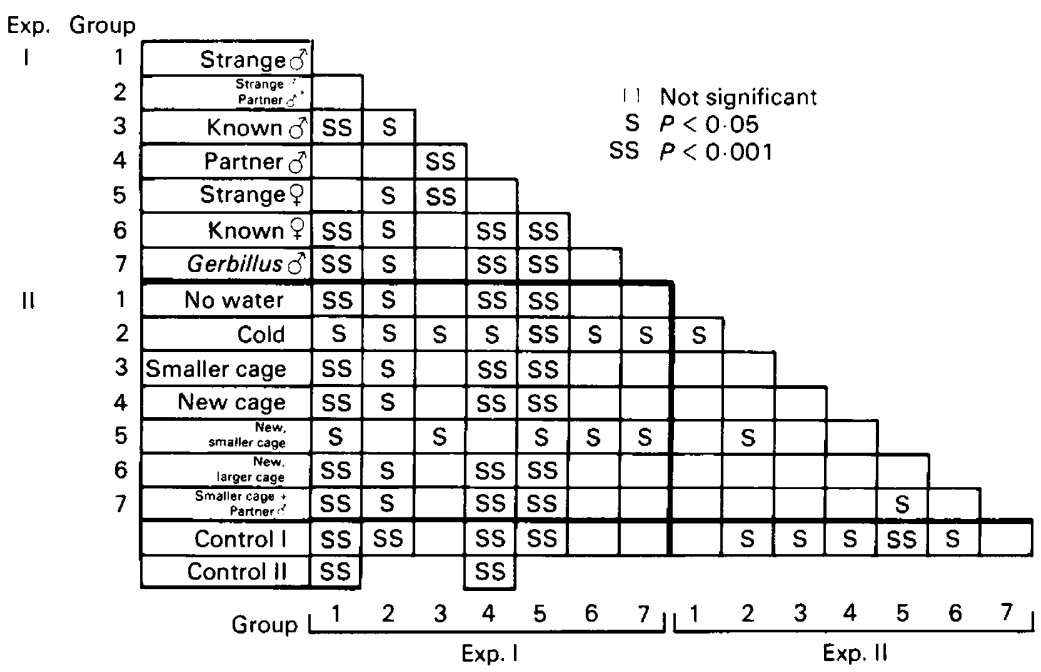

Text-fig. 2. Comparison of all social and non-social experiments and controls.

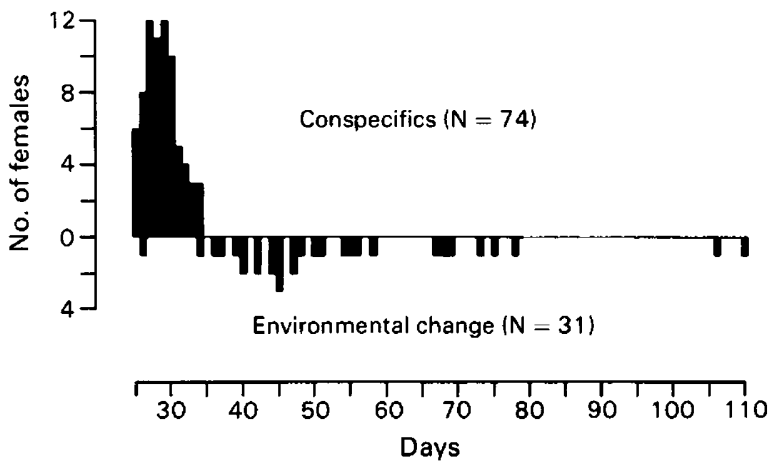

Text-fig. 3. Interval to the next litter of gerbils for females in which implantation had been blocked by conspecifics or environmental changes.

\section{Influence of strange males on neonates and lactating females}

Strange males and lactating females. Most rodents mate directly after every birth (post-partum oestrus), and females are usually pregnant while lactating. In natural conditions, therefore, implantation would normally be subject to inhibition in lactating females. Partner males were removed after copulation at the post-partum oestrus. The female and neonates remained in one compartment of a Type A cage, while a strange male was placed in the other compartment. In none of the 20 lactating females was implantation prevented. The presence of a strange male therefore does not prevent implantation in a lactating female.

Infanticide by strange males. According to the foregoing results, a male could terminate pregnancy only if he killed all the young. The behaviour of strange males towards infants was therefore examined. Infants at different stages of development (1-10 days old) were placed in the cages of adult isolated males (20 tests). Also, to test infant-related behaviour of males in cages strange to them, 5 males were placed singly in the infants' own home cage after removal of the female (5 tests). Observation lasted $1 \mathrm{~h}$. No male was aggressive to the strange young, which were sniffed at briefly and then ignored. 
Influence of strange males on young with the mother present. The presence of the mother might well affect the male's aggression to the young. Partner males were removed, and a strange male was substituted during or shortly after the female littered. The infant-related behaviour of the strange male was observed, and suckling time was noted on the first test day in 30-min intervals. In this and the following experiment females with litters of 4 young were used, or litters were reduced to 4 to give comparable conditions. The 10 tests ended after 5 days, or when all neonates had died. For Control I, the partner male was left in the cage with the female $(\mathrm{N}=10)$ and neonates, and for Control II, the female $(\mathrm{N}=10)$ remained alone with the neonates. The Mann-Whitney U-Test was used to check the statistical significance of the differences (Siegel, 1956).

Infant mortality was $95 \%$ in the 5 test days, significantly higher than in the controls $(P<$ 0.001 ) (Control I $4 \%$; Control II $6.25 \%$ mortality). This was obviously a consequence of neglect. Suckling time was significantly shorter $(P<0.001)$ in the test females $(15.3 \%$ of time $)$ than with the controls (Control I 92.9\%, Control II 94.3\%).

Influence of strange males in a separate compartment. After birth of a litter the partner male was removed from the divided Type A cage. The female plus young stayed in one compartment and a strange male was placed in the other. The young were weighed after 10 days. Suckling time during the 10 days was recorded daily at 30 -min intervals. For the control test, the partner male was transferred to the adjoining compartment after the female had littered.

Infants having a strange male as neighbour gained significantly less weight than controls (19.22 \pm 6.13 (s.d.) g compared with $33.81 \pm 3.38 \mathrm{~g} ; P<0.001$, Mann-Whitney U test). Female suckling time was significantly less with a strange male than with the partner male in the adjoining compartment $(63.8 \pm 17.3$ (s.d.) \% compared with $89.1 \pm 9.3 \%, P<0.01$, Mann-Whitney U test).

\section{Discussion}

The biological significance of the influence exerted by strange males on females, as evidenced in the Bruce effect, has not been explained to date. Dawkins (1976) and Wickler \& Seibt (1977) regard the effect as of evolutionary advantage for the strange males: a male succeeding in blocking an existing pregnancy can mate earlier with the female. A similar argument was used to explain infanticide in lions and primates (Mohnot, 1967; Schaller, 1972; Bertram, 1976; Hrdy, 1977; Angst \& Thommen, 1977; Struhsaker, 1977). But why should the female react so to the scent of a strange male? Is the reaction a mistake, or has it indeed evolutionary significance? Every female resisting such an influence could have more progeny. The present findings do not endorse Dawkins' (1976) assumption that the expediency of the Bruce effect could lie in enhanced male reproductive success. Pregnancy block in the Mongolian gerbil and all other investigated mouse species is limited to the first 4 or 5 days after coitus (Bruce, 1960b; Schwagmeyer, 1979) and to non-lactating females. But a newly mated female is normally suckling young. As strange males do not kill infants, their pregnancy-blocking influence is restricted to exceptional cases. Schwagmeyer (1979) suggests that the phenomenon may not be simply a product of male-male competition, and cannot be considered analogous to male infanticide in other species, as it involves the physiological response of the female, and there are constraints upon a male's ability to induce it (Bruce, 1959, 1960b, 1962, 1963; Parkes, 1960; Parkes \& Bruce, 1961).

But why do such a high percentage of females without young react to strange males? In studies of laboratory mice it was found that females need the male scent to become receptive (van der Lee \& Boot, 1955, 1956; Whitten, 1957, 1959; Whitten, Bronson \& Greenstein, 1968). Accordingly, the Bruce effect could be a special instance of the effect described by Whitten (1957) in that, like any non-pregnant female, a newly mated female still reacts to strange male 
scent for about 5 days, by coming into oestrus. This argument is supported by the finding that a female reacts to all males, except to the mating male, with a fresh ovulation. Even the partner male could terminate a pregnancy induced by a stranger (see Exp. I, Group 4). This observation is confined to Mongolian gerbils as yet, but the work of Lott \& Hopwood (1972) with Mus musculus leads to the conclusion that the female is 'sensitized' during copulation.

The finding that strange Mongolian gerbil females can also block a pregnancy supports the hypothesis on the functional significance of the Bruce effect. In laboratory house mice, juvenile, adult and ovariectomized females and castrated males had no influence on a pregnancy (Bruce, $1960 \mathrm{~b}, 1962$ ), so that here the effect was defined as implantation block released by strange males. In Peromyscus maniculatus strange females did block a pregnancy, but significantly less frequently than for strange males (Bronson \& Eleftheriou, 1963). The fact that gerbil males and females serve equally well to produce the Bruce effect strongly indicates that its development was not linked with male-male competition. This is supported by the finding that alterations in the cages also affect implantation in gerbils. As shown in Text-fig. 2, significantly fewer pregnancy blocks occurred in non-social than in social experiments. The same was found in Peromyscus maniculatus (Eleftheriou, Bronson \& Zarrow, 1962). The wild house mouse, Mus musculus, also reacts to such changes with a pregnancy block, but the laboratory mouse does not (Chipman \& Fox, 1966; Bruce, 1963). For gerbils, Norris \& Adams (1979) found no significant difference between pregnancy blocks caused by strange males or new cages and stress was considered to be responsible in each case. However, in the experiments of Norris \& Adams (1979), unlike those described in this paper, the strange male had direct contact with the female and it is possible that, in tests lasting 9 days, some females were resorbing and mating again immediately with the strange male.

The reaction in social experiments seems to stem from a reduction in prolactin secretion following contact with odours of conspecifics. The mechanism was described in detail by Parkes \& Bruce (1961). Mongolian gerbils excrete only minute amounts of urine in which no pheromones have so far been identified, and the specialized ventral sebaceous gland with its associated well established territorial marking function could play a part; individual identification via sebum odours is possible. Furthermore, in this sebum a pheromone has been identified (Thiessen, Regnier, Rice, Isaaks \& Lawson, 1974), the active part of which is phenylacetic acid.

I thank Prof. Dr W. Wickler for giving me the subject and for assistance throughout the study; Dr U. Seibt who placed the zoological material at my disposal and gave valuable advice; Dr J. Lamprecht, Dr C. Rechten and Dr U. Reyer for help with the manuscript; H. Birke for constructive criticism and the diagrams; $\mathrm{H}$. Klein for advice on statistical problems; and colleagues for stimulating discussions.

\section{References}

Angst, W. \& Thommen, D. (1977) New data and a discussion of infant killing in Old World monkeys and apes. Folia primatol. 27, 198-229.

Bertram, B.C.R. (1976) Kin selection in lions and in evolution. In Growing Points in Ethology, pp. 281-301. Eds B. B. G. Bateson \& R. A. Hinde. Cambridge University Press.

Bronson, F.H. \& Eleftheriou, B.E. (1963) Influence of strange males on implantation in the deermouse. Gen. comp. Endocr. 3, 515-518.

Bruce, H.M. (1959) An exteroceptive block to pregnancy in the mouse. Nature, Lond. 184, 105-106.
Bruce, H.M. (1960a) Further observation on the pregnancy block in mice caused by proximity of strange males. J. Reprod. Fert. 1, 311-312.

Bruce, H.M. (1960b) A block to pregnancy in the mouse caused by proximity of strange males. J. Reprod. Fert. 1, 96-103.

Bruce, H.M. (1962) Continued suppression of pituitary luteotrophic activity and fertility in the female mouse. J. Reprod. Fert. 4, 313-318.

Bruce, H.M. (1963) A comparison of olfactory stimulation and nutritional stress as pregnancyblocking agents in mice. J. Reprod. Fert. 6, 221-227. 
Bruce, H.M. \& Parrott, D.M.V. (1960) Role of olfactory sense in pregnancy-block by strange males. Science, N.Y. 131, 1526.

Chipman, R.K. \& Fox, K.A. (1966) Oestrus synchronization and pregnancy blocking in wild house mice. $J$. Reprod. Fert. 12, 233-236.

Clulow, F.V. \& Clarke, J.R. (1968) Pregnancy-block in Microtus agrestis, an induced ovulator. Nature, Lond. 219, 511.

Dawkins, R. (1976) The Selfish Gene. Oxford University Press, London.

Eleftheriou, B.C., Bronson, F.H. \& Zarrow, M.X. (1962) Interaction of olfactory and other environmental stimuli on inplantation in the deermouse. Science, N.Y. 137, 764.

Hrdy, B.S. (1977) Infanticide as a primate reproductive strategy. Am. Sci. 65, 40-49.

Lott, D.F. \& Hopwood, J.H. (1972) Olfactory pregnancy-block in mice. An unusual response. Anim. Behav. 20, 263-267.

Mallory, F.F. \& Clulow, F.V. (1977) Evidence of pregnancy failure in the wild meadow vole, Microtus pennsylvanicus. Can.J. Zool. 55, 1-17.

Mohnot, S.M. (1967) Some aspects of social changes and infant-killing in the Hanuman langur (Presbytis entellus). Mammalia 35, 175-199.

Norris, M.L. \& Adams, C.E. (1979) Exteroceptive factors and pregnancy block in the Mongolian gerbil (Meriones unguiculatus). J. Reprod. Fert. 57, 401404.

Parkes, A.S. (1960) The role of odorous substances in mammalian reproduction. J. Reprod. Fert. 1, 314322.
Parkes, A.S. \& Bruce, H.M. (1961) Olfactory stimuli in mammalian reproduction. Science, N.Y. 134, 10491054.

Schaller, G.B. (1972) The Serengeti Lion. University of Chicago Press.

Schwagmeyer, P.L. (1979) The Bruce-Effect: an evaluation of male/female advantages. Am. Nat. 114, 932-938.

Siegel, S. (1956) Nonparametric Statistics for the Behavioral Sciences. McGraw-Hill, New York.

Struhsaker, T.T. (1977) Infanticide and social organization in the redtail monkey (Cercopithecus ascanius schmidti). Z. Tierpsychol. 45, 75-84.

Thiessen, D.D., Regnier, F.E., Rice, M., Isaaks, N. \& Lawson, N. (1974) Identification of a ventral scent marking pheromone in the male Mongolian gerbil (Meriones unguiculatus). Science, N.Y. 184, 83-85.

van der Lee, S. \& Boot, I.M. (1955) Spontaneous pseudopregnancy in mice. Acta physiol. pharm. 4, 442-443.

van der Lee, S. \& Boot, I.M. (1956) Spontaneous pseudopregnancy in mice. Acta physiol. pharm. 5, 213-214.

Whitten, W.K. (1957) Effect of exteroceptive factors on the oestrous cycle in mice. Nature, Lond. 180, 1437.

Whitten, W.K. (1959) Occurrence of anoestrus in mice caged in groups. J. Endocr. 18, 102-107.

Whitten, W.K., Bronson, F.H. \& Greenstein, J.R. (1968) Estrus-inducing pheromones of male mice; transport by movement of air. Science, N.Y. 16, 584-585.

Wickler, W. \& Seibt, U. (1977) Prinzip Eigennutz. Hoffmann und Campe. 